\title{
ファジィモデリングによる地方交通施設整備の生活環境改善への影響評価* \\ An Evaluation of a Local Traffic Facility Construction on the Improvement of Living Environment Using Fuzzy Modeling*
}

加賀屋 誠 $一 * *$. 菊 池 慎 也***

By Seiichi KAGAYA** and Shinya KIKUCHI***

\section{1.はじめに}

建設省はその道路整備の長期構想において、活力ある 経済活動に支えられたゆとり社会の実現のために基本的 方向を1)豊かな生活の実現、2)活力のある地域つくり、 3)人・自然にやさしい環境の形成の主要課題において整 備の推進を図っている。その内容には、円滑なモビリ ティの確保、安全なモビリティの確保などと共に、快適 な生活環境の創造、高規格幹線道路を中心とした交流 ネットワークの充実、地域集積圈の形成などがあげられ ている。さらに、地域振興施策の支援、地球温暖化の防 止、自然環境との調和などの環境の保全と形成も含まれ ている1)。

ここでは、道路整備の多椂性が指摘されると共に、地 域社会とそれを構成する住民に、より身近な生活空間と しての道路施設整備の姿勢がみられている。このように 道路整備を生活空間の量的・質的改善と関連つけること は生活環境の量・質を高めることの中心的役割を自らに 課しているといえる。このように考えると道路整備に伴 う地域への多様な影響を計測する方法の確立も益々必要 性を増してきている。すなわち生活環境全般に対する道 路整備効果の新たな評価方法が必要となってきているの である。ここでは、地方道路の整備が、整備対象地域の 生活環境改善にどの程度寄与しているかを地域住民の認 識構造評価によって検討する方法を提案し、今後の道路 施設整備の支援システムへの活用を考察することを目的 とする。

住民の認識構造は、正確な表現をしようとすれば非常 に複雑で非確定的な性質を持っている。したがって

*キーワード : 整備効果計測法、意識調査分析、環境計画 $* *$ 正員、学博、北海道大学工学部土木工学科(060 札幌市北 区北13条西8丁目、TEL011-706-6210,FAX011-726-2296), *** Ph.D.,Dept. of Civil Engineering, University of Delaware, Newark, Delaware 19716,TEL 302-831-2657,FAX302-831-3640)
そのような主観システムを構筑するとすれば人間が自然 言語で表現する場合のようなあいまいな情報を的確に表 現できる要約能力を必要とする。すなわち、主観的なシ ステムを内包するシステムは、もともと多義性、あいま い性、蓋然性、無知性などを要約的に表現する能力を もっていなければならない2)。ここで採用した様相性 ファジィモデリングは、特に、現象あるいは事実を可能 的から、必然的までの人間が持つ主観の広範な様相に着 目して、要約能力を高め、人間の価値判断過程を忠実に 再現するモデルであるといえる。ここで可能的とは、実 行可能な程度や達成の容易さなどの認知に関係するもの で僅かであれ認知性が存在する場合の様相を表す。ま た、必然的とは、確実に起こりうるものあるいは認めら れるものの様相を表す。

\section{2 検郡方法と対象地域}

\section{(1)検討方法と手順}

地方道路整備がもたらす地域への影響は、一般的に次 のような変化として把握される。

a)整備効果としては、経済や効率といった直接的側面の みではなく生活レベルの向上をもたらす間接的な効果が 期待されその把握が重要である。

b)具体的に計測可能な効果よりはむしろ、心理的な質的 効果が期待されそのことが地域活性化への役割を果た す。

c)道路整備によって道路騒音、交通事故などそれまでに なかったデメリットも明確に現れてくる。 d)今後期待される道路整備のあり方も、単一目的の達成 ではなく、総合的な目的を持つことが期待される。

以上のような視点に着目し、地域住民の認識構造を把 握し、それらの意識情報を要䄪する方法として様相性 ファジィモデリングの適用を考えた 3$)$ 。そのモデルは具 体的には可能性、必然性とその中間的測度で計測された 意思決定者（住民）の主観的評価 3 )をもとにその認識構 
造の決定を行なう方法である。その手順は、図 1 に示さ れる4)。

交通施設整備による生活環境改善度調査

（調查票による世帯主調查）

言語変数による表現と言語值による解析

(ラベル化されたメンバーシップ関数表示)

$\downarrow$

ファジィ効用差関数の決定と選好性の評価

（ファジィ測度とファジィ寄与ルール法の適用）

$\downarrow$

グループによる各評価属性の選好性の決定

（ハミング最近接関係の適用）

各評価属性間の構造化

（ファジィ構造化手法FSMの適用）

各属性の総合化による整備事後評価

(Choquet積分による総合評価のファジィモデリング)

$\downarrow$

交通施設整備事後評価法の検討

図1 検討方法と手順の概要

i)ここでは、いくつかの評価項目によって交通施設整備 に関わる改善度、および地域の生活環境に及ぼす影響を 調查した。評価項目は、地域改善度評価項目として、あ らかじめ17項目選び、そのいくつかの組み合わせも同時 に考えた。そして被験者である住民に素質問として分類 的（選択肢）質問をした。

ii)それらを言語変数として定義し、5 種類のラベル表示 の言語值を用いそれぞれの言語変数の部分集合ラベルと した。これをファジィ効用值として定義する。

iii)これらのファジィ効用值をそれぞれ 1 対の評価項目ご とに、拡張原理（ファジィ代数）によって差をとりファ ジィ効用差関数を作成する。また、効用差の判定を各評 価属性間の選好関係に対応させるために寄与ルール法を 導入する。ここではファジィ測度での効用差一選好強度 の写像で定式化を行っているので、ファジィ奇与ルール 法(Fuzzy Contribution Rule-FCR)として定義する。 iv)iii)で得られた選好関係を集団に拡張する。ここでは個 人の各項目ごとの効用差関数の中間値を求めることに
よって、集団効用差関数が定義される。得られた集団効 用差関数は、ファジィ寄与ルールによって選好性が評価 される。ここでは、2つの項目間での選好性を判断する ファジィ効用差が正か負かを見極めるためには、その差 を認識するための可能性から必然性への様相を適用す る。これがファジィ測度での主観計測の考え方である。 v)算定された奇与ルール値の大小を相対的な選好強度と して、各評価属性間の構造化をファジィ構造化手 法(FSM)によって行う。

vi)さらに、各属性の効用の総合化による整備事後影響評 価を行なう。ここでは、Choquet積分によるファジィモデ リングを適用する。

vii)最後に、ここで用いられた交通施設整備による改善 度・生活環境満足度評価の結合による評価結果について 考察検討をする。

なお本手順では、ファジィ効用差関数の定義、従来の 方法からファジィ寄与ルール法への拡張、グループ効用 評価、Choquet積分での相乗・相殺効果評価法などここで 新たに開発を試みたものである。

\section{(2)対象地域と交通施設鳌備}

本研究の対象地域は、北海道滝上町である。滝上町は 紋別市と旭川市を結ぶ国道273号沿線にあり人口4,499人( 1990年)の畑作と林業が中心の町である。また、対象とな る交通整備施設としては、滝上町一上川町を結ぶ国道27 3号浮島トンネルで1984年に開通した。同トンネルの開 通により、滝上町、紋別市から、近隣中核都市旭川市へ のアクセスが大きく改善された。トンネル開通での周辺 地域の変化を示すと以下のようになる。

i)国道273号浮島峠を利用する交通は整備直後から年々着 実に増加している。図 2 は整備前後の交通量の変化を表 したものである。その結果整備前後で、約200\%の増加が みられている。

ii)表 1 は整備前後の走行距離と所要時間の短縮状態を、 通常時(無雪期) と冬季（積雪期）の場合で表したもので ある。ここでは、整備後紋別〜旭川間で $26.7 \mathrm{~km} \mathrm{32}$ 分、 滝上〜旭川間で $6.9 \mathrm{~km} 11$ 分の短縮が図られ、冬季間にお いては、それぞれ39分、72分の短縮がみられた。特に、 冬季間滝上〜旭川間で大幅な短縮がみられたのは、峠の 通年利用が確保できたためである。

iii)短縮時間と交通量から直接便益として走行便益と時間 便益を概算すると前者は 11 億円、後者は6億4千万円とな 
る。

iv)地域産業への影響として最も大きい効果は、観光入り 込みであり、特に滝上町では、整備直後 $40 \% 、 5$ 年後 9 0\%と著しい上昇がみられる。

v)一方悪影響としては、交通事故の増加がみられた。す なわち、整備前 5 年間の人身事故が5.75件/年であった が、整備後の平均は、15.2件/年であった。その件数は、 年を追うごとに増加の傾向がある。

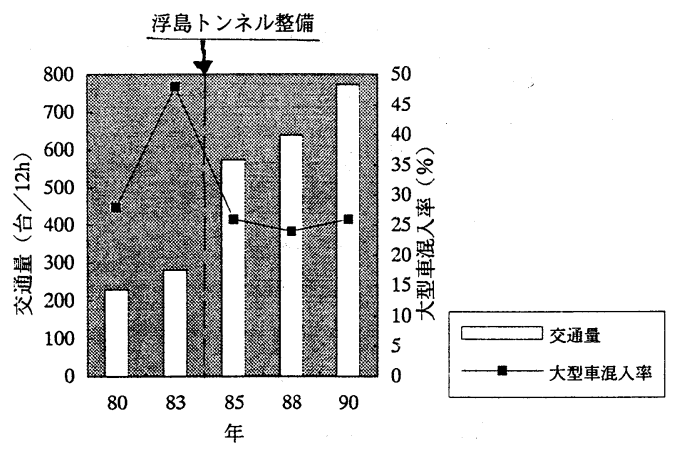

図2 交通量の推移

表 1 トンネル整備による走行距離・所要時間の短縮

\begin{tabular}{|l|c|c|c|c|}
\hline \multirow{2}{*}{ 区間 } & \multicolumn{3}{|c|}{ 通常時 (無雪時) } & \multicolumn{3}{|c|}{ 冬季（積雪時） } \\
\cline { 2 - 5 } & 走行距離 & 所要時間 & 走行距離 & 所要時間 \\
\cline { 2 - 5 } & $(\mathrm{km})$ & $($ 分 $)$ & $(\mathrm{km})$ & (分) \\
\hline 紋別 旭川 & 6.9 & 11 & 26.7 & 39 \\
\hline 滝上〜旭川 & 6.9 & 11 & 44.4 & 72 \\
\hline
\end{tabular}

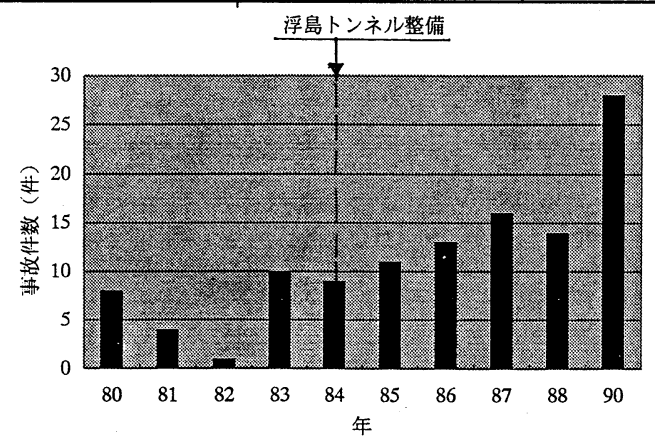

図3 交通事故（人身事故）の推移

このように、整備効果や問題点は、直接的効果として 多義的に捉えられるが、ここではそのような直接的な道 路施設改善と共に間接的質的な地域住民に対する影響を 評価することが主たる目的である。ちなみに、直接的な 効果とその認識との関係については、相互のハイブリッ ドなシステム構築も行われている5)。ここでは住民の効 用評価をべースにした道路施設整備の評価方法を以下の
議論で検討する。すなわち住民の道路施設整備に対する 評価が生活環境全般への影響に波及しているという仮定 に基づき、議論を進める。住民の生活環境評価要因の枠 組みとして、次のようなものを考える。

i)一般交通条件改善による生活環境に関わる影響評価 ii)交通施設整備による生活環境関連項目重要度

調査は、前述した滝上町内に住む世帯主122名を無作 為に選び、調查票を用いて行なった。ちなみに、標本数 は95\%信頼度で精度が士0.08であり、一般の統計調查に 比べ精度がやや粗いといえるが得られた回答をファジィ 数としてあらかじめある程度大きな幅をもつものとして いる。ここではファジィ測度が標本数が少なくてもその 結果に意味を持つことも合わせて検討していく。

\section{3 本システムのアルコリズムと考え方}

\section{(1)交通施設整備による生活㻴境改善度調查}

ここでは、それぞれの質問選択肢を 5 段階のラベルの 言語変数を用い、それらの言語值をファジィ数に近似し て表す。例えば、改善度評価の場合、「非常によくなっ た」、「まあまあよくなった」、「変わらない」、「か えって悪くなった」、「非常に悪くなった」の 5 段階の 修飾子付ファジィ記述形容詞（言語値）を用いる。

実際の質問から得られた結果は言語值まで拡張原理に よってファジィ代数演算を行ってもよいが、より弾力的 な演算ができるように以下のようにファジィ数化し三角 型メンバーシップ関数で表す。例えば、上記の改善度を 表す関数は、以下のようになる。

Very $\operatorname{good}\left(\mathrm{a}_{\mathrm{i}}, \mathrm{k}\right)=[4,5,5] \quad$ (非常によくなった）

Fairy $\operatorname{good}\left(\mathrm{a}_{\mathrm{i}}, \mathrm{k}\right)=[3.4 .5]$ （まあまあよくなった）

not good and not $\operatorname{bad}\left(\mathrm{a}_{\mathrm{i}}, \mathrm{k}\right)=[2,3,4] \quad$ （変わらない）(1)

fairly $\operatorname{bad}\left(\mathrm{a}_{\mathrm{i}}, \mathrm{k}\right)=[1,2,3]$ （かえって悪くなった）

$\operatorname{very} \operatorname{bad}\left(\mathrm{a}_{\mathrm{i}}, \mathrm{k}\right)=[0,1,1] \quad$ （非常に悪くなった）

ただし(1)の[]内はそれぞれ三角形の[下限値、中央 值、上限値]を表す。またここで $\mathrm{a}_{\mathrm{i}}$ は評価項目、 $\mathrm{k}$ はサン プル番号を示す。ちなみに、ファジィ数の導入は、記述 形容詞のあいまい性に幅とその㷌属性を考虑したことで ある。したがって、ここでの三角型メンバーシップ関数 は、各整数の意味する範囲の限界までをとることにし た。

(2)ファジィ効用差関数とファジィ奇与ルール法

奇与ルール法は、椹木等によって開発された合意形成 や代替案評価のための方法である6)。ファジィ寄与ルー 
ル法は、人間の主観性を計画情報として導入するため の、浅い知識や直感的な情報の忠実な数学的表現が可能 なファジィ理論と意思決定者グループの集団的効用総和 を算定し、その大小によって選好構造を決定する奇与 ルール法を結合したもので、より弾力的な意思決定情報 を与えることができる。ここでは、各集合の構成要素の 選好構造を求め、各質問回答の全体構造を検討するのに 用いる。今、各項目の中で、1 対の項目 $\mathrm{a}_{\mathrm{i}}$, 多を考える。 意思決定者 $k$ が、集団の選好に寄与する量を表す関数 $\widetilde{\mathbf{C}}$ (contributive function) を用いてその選好性を次のように定 義する。

$a_{i} R_{j} \quad$ iff $\widetilde{C} k_{m}\left(a_{i}, a_{j}\right) \geqq 0$

$\widetilde{\mathrm{C}} \mathrm{k}_{m}\left(\mathrm{a}_{\mathrm{i}}, \mathrm{a}_{\mathrm{j}}\right)=\widetilde{\mathrm{u}}_{\mathrm{m}}\left(\mathrm{a}_{\mathrm{i}}\right)-\widetilde{u} \mathrm{u}_{\mathrm{m}}\left(\mathrm{a}_{\mathrm{j}}\right)$

ここで、 $a_{i} R a_{j}$ は、意思决定者 $k$ とって、 $a_{i}$ は、 $a_{j}$ より好 ましいか、同程度に好ましいことを表し、ファジィ連結 律とファジィ推移律を満足する。

$\widetilde{\mathrm{C}} \mathrm{k}_{\mathrm{m}}\left(\mathrm{a}_{\mathrm{i}}, \mathrm{a}_{\mathrm{j}}\right)$ は、意思決定者 $\mathrm{k}$ の $\mathrm{a}_{\mathrm{i}}$ の $\mathrm{a}_{\mathrm{j}}$ に対する効用差すなわ ち選好強度を示す。すなわちこれは、意思決定者 $\mathrm{k}$ が $\mathrm{a}_{\mathrm{i}} に$ 対して持つファジィ効用 $\left.\tilde{u}_{\mathrm{m}} \mathrm{a}_{\mathrm{i}}\right) \mathrm{a}_{\mathrm{j}}$ に対して持つファ ジィ効用 $\tilde{\mathbf{u}} \mathrm{k}_{\mathrm{m}}\left(\mathrm{a}_{\mathrm{j}}\right)$ の差の関数である。これらのファジィ効 用値は、(1)で示した意思決定者の言語値で表現されるも のであり、(3)式は通常のファジィ代数（拡張原理によ

る）で算出される。また選好強度が正か負かを計測する ファジィ測度を、 $\mu_{\mathrm{R}} \mathrm{k}_{\mathrm{m}}\left(\mathrm{a}_{\mathrm{i}}, \mathrm{a}_{\mathrm{g}}\right)$ と表すこととすると

(4)が得られる。

樣相性は、関数 $\mu_{\mathrm{R}} \mathrm{k}_{\mathrm{m}}\left(\mathrm{a}_{\mathrm{i}}, \mathrm{a}_{\mathrm{j}}\right)$ が、どの程度 $\mathrm{Ck}_{\mathrm{m}}\left(\mathrm{a}_{\mathrm{i}}, \mathrm{a}_{\mathrm{j}}\right) \geqq 0$ の条件を満たす領域にあるか否かで判定される。効用差 関数を表したのが、図 4 である。

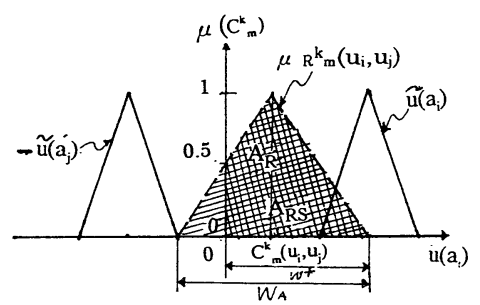

図4 効用差関数の算定

(単一意思决定者[住民]の場合)

ファジィ測度は人間の思考過程を最も忠実に表す測度 であると考えられる。(ここでは可能性から必然性までの 幅を持った計測値をとる。）ファジィ測度の様相による 違いを図 5 に表す。

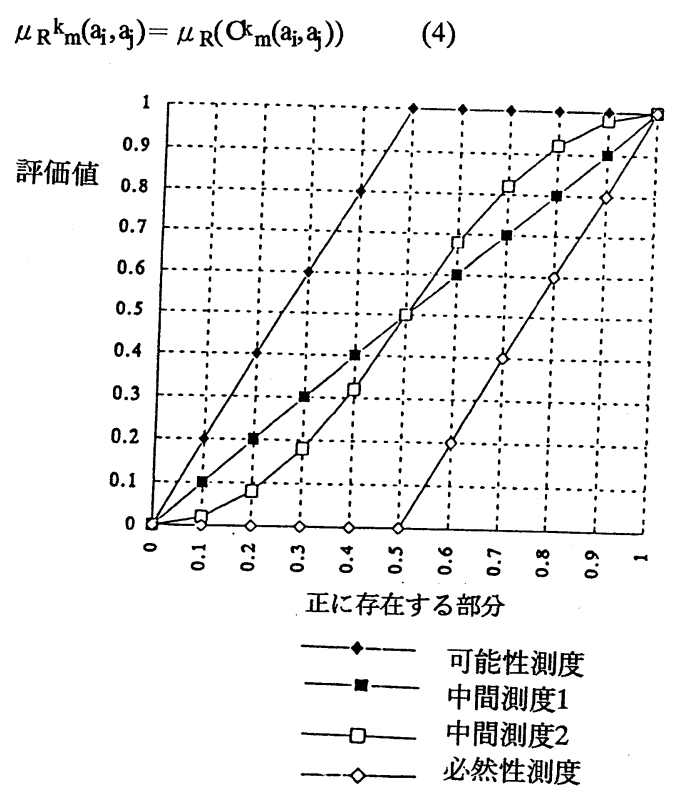

図5＼cjkstart様相性の違いによるファジィ測度による評価 可能性測度、必然性測度は(5) (6)によって決定される。

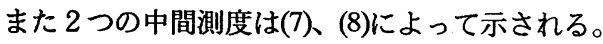
可能性測度: $\left.\Pi(\mathrm{R})=\sup \left(\pi_{\mathrm{RS}}\left(\mathrm{O}_{\mathrm{m}}\left(\mathrm{a}_{\mathrm{i}}, \mathrm{a}_{\mathrm{j}}\right)\right) \wedge \mu_{\mathrm{R}} \mathrm{k}_{\mathrm{m}}\left(\mathrm{a}_{\mathrm{i}}, \mathrm{a}_{\mathrm{j}}\right)\right)\right)(5)$ 必然性測度: $\left.N(R)=\inf \left(1-\pi_{R S}\left(O_{m}\left(a_{i}, a_{j}\right)\right) \vee \mu_{R} k_{m}\left(a_{i}, a_{j}\right)\right)\right)(6)$ ただし、Ck ${ }_{m}\left(a_{i}, a_{j}\right) \geqq 0$ のとき $\pi_{R S}\left(O_{m}\left(a_{i}, a_{j}\right)\right)=1$

$$
\mathrm{Ck}_{\mathrm{m}}\left(\mathrm{a}_{\mathrm{i}}, \mathrm{a}_{\mathrm{j}}\right)<0 \text { とき } \pi_{\mathrm{RS}}\left(\mathrm{Or}_{\mathrm{m}}\left(\mathrm{a}_{\mathrm{i}}, \mathrm{a}_{\mathrm{j}}\right)\right)=0 \text { である。 }
$$

中間測度 $1: a_{i j}=w^{+} / w_{A}$

ただしW $\mathrm{A}_{\mathrm{A}}$ は図 4 における効用差の全範囲、w+は正の部 分の範囲を表す。

中間測度 $2: c_{i j}=\left(A_{R S} \cap A_{R}\right)$ の面積 $/ A_{R}$ の面積 $)(8)$ ただし $A_{R S}$ は効用差関数 $\mu_{\mathrm{R}} \mathrm{k}_{\mathrm{m}}\left(\mathrm{a}_{\mathrm{i}}, \mathrm{a}_{\mathrm{j}}\right)$ が正の領域に占める 面積、 $A_{R}$ は $\mu_{R^{k}}{ }^{k}\left(a_{i}, a_{j}\right)$ が占める全面積を示す。

\section{(3)ダループファジィ選好関係の決定}

上述のファジィ効用差関数および選好関係決定を示す ファジィ測度は、単一意思決定者に関する議論である。 次に複数意思決定者のグループの選好関係を定義するこ ととする。意思決定者グループでの選好関係は各メン バー間の選好関係の中の最近接ファジィ関係を見つける ことで決定される。実際には拡張原理に基づくファジィ 代数で平均值を求め決定する方法が厳密解と考えられる が、ファジィ代数の場合、意思決定者の数が多ければ多 いほどその定義域が広がり、実際の選考関係を決定する 
には現実的ではない。したがってここでは、各意思決定 者の選好関係を表す効用差関数を小さいものから順に配 列しその中での中間值(median)となる関係をグループの 代表値と定義する。そのアルゴリズムについては、以下 のようになる5)。

今、q人の意思決定者をそれぞれメンバー1,メンバー $2, \ldots$, メンバーqとし、それぞれのファジィ関係を簡略的 $に \mu_{\mathrm{R}}{ }^{1}{ }_{\mathrm{m}}\left(\mathrm{a}_{\mathrm{i}}, \mathrm{a}_{\mathrm{j}}\right), \mu_{\mathrm{R}}{ }^{2} \mathrm{~m}\left(\mathrm{a}_{\mathrm{j}}, \mathrm{a}_{\mathrm{j}}\right), \ldots . ., \mu_{\mathrm{R}} \mathrm{q}_{\mathrm{m}}\left(\mathrm{a}_{\mathrm{i}}, \mathrm{a}_{\mathrm{j}}\right)$ ように表しそ れらの最近接ファジィ関係を $\mu_{\mathrm{R}} \mathrm{N}_{\mathrm{m}}\left(\mathrm{a}_{\mathrm{i}}, \mathrm{a}_{\mathrm{j}}\right)$ とすると、その 関係は(9)によって得られる。

$\mu_{\mathrm{R}} \mathrm{N}_{\mathrm{m}}\left(\mathrm{a}_{\mathrm{i}}, \mathrm{a}_{\mathrm{j}}\right)=\min \sum \mathrm{d}\left(\mu_{\mathrm{Rm}}\left(\mathrm{a}_{\mathrm{i}}, \mathrm{a}_{\mathrm{j}}\right), \mu_{\mathrm{R}} \mathrm{k}_{\mathrm{m}}\left(\mathrm{a}_{\mathrm{i}}, \mathrm{a}_{\mathrm{j}}\right)\right)(9)$

$R$

ここで $\mu_{\mathrm{Rm}}\left(\mathrm{a}_{\mathrm{i}}, \mathrm{a}_{\mathrm{j}}\right)$ は任意の意思決定者の項目 $\mathrm{m}$ でのファ

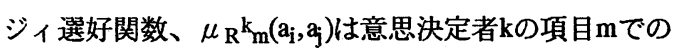

ファジィ選好関数を表す。(9)によって一般的な最近接

ファジィ関係を決めることができるが、具体的な方法は 次の(10)に示す中央值で代表させるプロセスをとる。す なわち、まず次のように各自のファジィ選好関数を昇順 に並べ替えを行う。

$\mu_{\mathrm{R}}{ }^{1} \mathrm{~m}\left(\mathrm{a}_{\mathrm{i}}, \mathrm{a}_{\mathrm{j}}\right) \leqq \mu_{\mathrm{R}}{ }^{2} \mathrm{~m}\left(\mathrm{a}_{\mathrm{j}}, \mathrm{a}_{\mathrm{j}}\right) \leqq \ldots \ldots . . \mu_{\mathrm{R}} \mathrm{q}_{\mathrm{m}}\left(\mathrm{a}_{\mathrm{i}}, \mathrm{a}_{\mathrm{j}}\right)$

次に最近接ファジィ関係を次のように定義する。

$\mu_{\mathrm{R}} \mathrm{N}_{\mathrm{m}}\left(\mathrm{a}_{\mathrm{i}}, \mathrm{a}_{\mathrm{j}}\right)=\mu_{\mathrm{R}^{\mathrm{k}} \mathrm{m}}\left(\mathrm{a}_{\mathrm{i}}, \mathrm{a}_{\mathrm{j}}\right)$

（もし qが奇数の時 $\mathrm{k}=(1 / 2)(\mathrm{q}+1)$ として）

$\mu_{R} N_{m}\left(a_{i}, a_{j}\right)=1 / 2\left(\mu_{R} k_{m}\left(a_{i}, a_{j}\right)+\mu_{R}{ }^{k+1} m\left(a_{i}, a_{j}\right)\right)$

（もしqが偶数の時 $\mathrm{k}=(1 / 2) \mathrm{q}$ として）

この方法によって、集団のファジィ選好関数が選択さ

れ、ハミング最近接関係を求めたことになる。

\section{(4)FSMによる远好性のグラフ粠造}

FSM法は、ファジィ従属関係マトリクスを基本とし、い くつかの抽出した要因の階層化を行ない、階層間ならび に、階層に属する要因間の従属関係を決定して、それを グラフ表現することを目標にした方法である。ここで は、(3)で得られた関係の強さによって、マトリクスを 決定する。すなわち、ファジィ従属マトリクスの場合 の各要素は、図5に示すように可能性測度と必然性測度 の間に定義された様々な值をとることができる。得られ たマトリクスの各要素は、選好性を求める要因 (項目) の一方が他方に従属する゙ らしざの強さである。この 場合、関係の強さに闘値を設けることによって、その序 列関係を決定する。闘値は、任意にとることができる
が、閾値を高くすると各項目間の独立性が強くなり、相 互の関連性が弱まる。ファジィ構造化は、その方法にお いて 2 值データでの構造化と類似している。しかしなが ら、集合の領域に幅があることからその範囲を設定する ことによって、補集合の影響が変わり、関係の強さも変 化する。したがって、闘値pと補集合を決定する範囲を 表すパラメータ $\mathrm{c}$ cを定めることによって関連構造が決 定される。FSMは選好構造をその結合の強さ（閆値p 補集合決定パラメータで表される）によって変化させ、 解釈しやすくしたものであり、ISMの拡張型といえる。

\section{(5)Choquet積分による総合評価法}

一般に、複数の項目を有するシステムに対する評価を 行なうとき、項目間の相乗性や相殺性のために総合化に おいて、加法性では説明できない結果があらわれる。す なわち、個々の項目における評価を単に加えても総合的 評価值を推測できない場合である。このような場合は、 加法性条件を緩和し、単調性のみによって結合される総 合化のアプローチが必要である7)。ファジィ測度は、そ のような単調性のみによって定義される測度であるか ら、その測度分布を利用した総合化がその手段の 1 つと なる。ファジィ測度によるファジィ積分の方法がそれを 可能にしている。ここでは、ファジィ積分の 1 つとして Choquet積分を導入し検討する。

$(\mathrm{X}, \mathrm{A}, \mathrm{g})$ をファジィ測度空間、fをX上の非負実数値可測関 数とする。fの一般ファジィ測度gに関するChoquet積分 は(11)で定義される。また $\mathrm{f}\left(\mathrm{x}_{\mathrm{i}}\right)$ は評価基準 $\mathrm{x}_{\mathrm{i}}$ に対する評価 値を表しているともいえる。

(C) $\int f d g=f\left(x_{n}\right) g\left(A_{n}\right)+\left[f\left(x_{n-1}\right)-h\left(x_{n}\right)\right] g\left(A_{n-1}\right)+\ldots$.

$$
\begin{aligned}
& +\left[f\left(x_{1}\right)-f\left(x_{2}\right)\right] g\left(A_{1}\right) \\
= & =\sum_{i=1}^{n}\left(f\left(x_{i}\right)-f\left(x_{i-1}\right)\right) g\left(A_{i}\right) .
\end{aligned}
$$

ただし、 $A_{i}=\left\{x_{i}, x_{i+1}, \ldots, x_{n}\right\}, A_{0}=0$

ここでは、(11)での $g\left(A_{i}\right) に$ 重要度の評価値を(3)によっ て導きだし、 $\mu_{\mathrm{R}} \mathrm{k}_{\mathrm{m}}\left(\mathrm{a}_{\mathrm{i}}, \mathrm{a}_{\mathrm{j}}\right)$ の大きさにより相対的重みを算 出した。この積分法を用いて、ファジィ総合評価を検討 する。

\section{4 .交通施設整橵に伴う生活改善度評価と考察}

交通施設整備に伴う、地域住民の生活改善度の評価項 
目としては、表 2 のような17項目を選択した。ここでは それらの項目の独立性を特に問わず、評価はファジィ測 度によって行うものとした。また、ファジィ構造 化(FSM) に用いるしきい值は、いくつかの組み合わせ

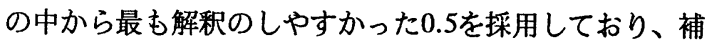
集合を決定する係数 $\lambda_{\mathrm{c}}$ は-0.05を用いて、計算を行なっ ている。ここではファジィ寄与ルール法で得られた効用 差関数をファジィ測度で評価、さらにハミングの最近接 関係によって集団の選好性を評価することとする。

表 2 交通施設整備に伴う生活改善度評価項目

\begin{tabular}{|l|c|}
\hline \multicolumn{1}{|c|}{ 項 目 } & 記号 \\
\hline 買い物など日常生活の利便性 & $\mathrm{A}$ \\
\hline 医療施設への通院や救急医療 & $\mathrm{B}$ \\
\hline 近隣地域への接近性 & $\mathrm{C}$ \\
\hline 観光レジャー地域への便 & $\mathrm{D}$ \\
\hline 業務や出張の便 & $\mathrm{E}$ \\
\hline 芸術・スポーツ・教育などの便 & $\mathrm{F}$ \\
\hline 歩行者の安全性 & $\mathrm{G}$ \\
\hline 冬季走行時の安全性 & $\mathrm{H}$ \\
\hline 走行時の快適性 & $\mathrm{I}$ \\
\hline 自動車公害の軽減 & $\mathrm{J}$ \\
\hline 自然環境の保全 & $\mathrm{K}$ \\
\hline 景観・風土の保全 & $\mathrm{L}$ \\
\hline 風雨・豪雪等の災害に対する安全性 & $\mathrm{M}$ \\
\hline まの産業の活性化 & $\mathrm{N}$ \\
\hline 観光などの振興 & $\mathrm{O}$ \\
\hline まちの清潔さ & $\mathrm{P}$ \\
\hline まちの治安 & $\mathrm{Q}$ \\
\hline
\end{tabular}

はじめに全サンプルのデータを用いて、各測度の違い による構造の同定を行う。表 3 は全体の場合の、 4 つの 測度の違いによる選好構造を表したものである。これに よると、可能性測度が最も選好序列がよく現れており、 逆に必然性測度は、選好序列の識別が明確でない。すな わち様相による特性がそれぞれの測度評価によって明ら かになった。

\section{表3 ファジィ測度の違いによる構造同定}

\begin{tabular}{|l|l|}
\hline 評価測度 & 改善度項目の選好順序 \\
\hline 可能性測度 & $\mathrm{B}>\mathrm{D}=\mathrm{A}>\mathrm{C}=\mathrm{E}>\mathrm{O}>\mathrm{I}>\mathrm{N}>\mathrm{H}>\mathrm{F}=\mathrm{M}>\mathrm{L}>\mathrm{P}>\mathrm{Q}>\mathrm{K}>\mathrm{G}=\mathrm{J}$ \\
\hline 中間測度 1 & $\mathrm{~A}=\mathrm{B}=\mathrm{C}=\mathrm{D}=\mathrm{E}=\mathrm{O}>\mathrm{I}=\mathrm{H}=\mathrm{N}=\mathrm{F}=\mathrm{M}>\mathrm{K}=\mathrm{L}=\mathrm{P}=\mathrm{Q}=\mathrm{G}=\mathrm{J}$ \\
\hline 中間測度 2 & $\mathrm{~A}=\mathrm{B}=\mathrm{C}=\mathrm{D}=\mathrm{E}=\mathrm{O}>\mathrm{I}>\mathrm{H}=\mathrm{N}>\mathrm{F}=\mathrm{N}>\mathrm{K}=\mathrm{L}=\mathrm{P}=\mathrm{Q}>\mathrm{G}=\mathrm{J}$ \\
\hline 必然性測度 & $\mathrm{A}=\mathrm{B}=\mathrm{C}=\mathrm{D}=\mathrm{E}=\mathrm{O}>\mathrm{I}=\mathrm{H}=\mathrm{N}=\mathrm{F}=\mathrm{M}>\mathrm{K}=\mathrm{L}=\mathrm{P}=\mathrm{Q}=\mathrm{G}=\mathrm{J}$ \\
\hline
\end{tabular}

次に、表4は、中間測度 2 をフジィ測度として用い て構造同定を行った結果である。ここでは全体の場合 と、各世代による違いを検討したものである。

これをみると、トンネル整備評価として、医療施設へ の通院や救急医療、観光レジャ一地域への接近性、買物
などの日常生活の利便性、業務出張の便、近隣地域への 接近性、観光などの振興を強く最も上位にあげている。 次に、快適性、走行時の安全性、まちの産業の活性化な どをあげている。また、一方、歩行者の安全性、自動車 公害の軽減がそれに比べ低い評価である。トンネルの開 通による交通量の增加と、その事故への影響を危惧して いることが現われている。

また、年齢別の選好順位をみると、高年齢層では、医療 施設への利便性が向上したとする反応が高いが、若年層 では、業務や買い物などの日常生活の利便性に高い評価 を与えていることがわかる。道路整備評価に対する世代 の違いが明確に現れている。

表4 交通施設整備による生活改善度選好順位

\begin{tabular}{|l|l|}
\hline 年秢構成 & 選好順位（ $>$ は優越性、 $=$ は無差別性） \\
\hline 全体 & $\mathrm{A}=\mathrm{B}=\mathrm{C}=\mathrm{D}=\mathrm{E}=\mathrm{O}>\mathrm{I}>\mathrm{H}=\mathrm{N}>\mathrm{F}=\mathrm{N}>\mathrm{K}=\mathrm{L}=\mathrm{P}=\mathrm{Q}>\mathrm{G}=\mathrm{J}$ \\
\hline $26-40$ 歳 & $\mathrm{E}>\mathrm{A}>\mathrm{D}>\mathrm{C}=\mathrm{I}>\mathrm{B}>\mathrm{O}>\mathrm{F}>\mathrm{H}=\mathrm{N}>\mathrm{M}>\mathrm{J}=\mathrm{L}>\mathrm{P}>\mathrm{Q}>\mathrm{G}>\mathrm{K}$ \\
\hline $41-50$ & $\mathrm{D}>\mathrm{B}>\mathrm{C}>\mathrm{A}=\mathrm{E}>\mathrm{O}>\mathrm{I}>\mathrm{N}>\mathrm{F}>\mathrm{M}>\mathrm{H}>\mathrm{P}>\mathrm{L}>\mathrm{J}=\mathrm{K}>\mathrm{Q}>\mathrm{G}$ \\
\hline $51-65$ & $\mathrm{~B}>\mathrm{D}>\mathrm{C}>\mathrm{E}=\mathrm{O}>\mathrm{A}>\mathrm{I}=\mathrm{N}>\mathrm{F}>\mathrm{H}>\mathrm{M}>\mathrm{P}>\mathrm{Q}>\mathrm{K}=\mathrm{L}>\mathrm{G}=\mathrm{J}$ \\
\hline 66 歳以上 & $\mathrm{O}>\mathrm{B}>\mathrm{D}>\mathrm{A}>\mathrm{C}>\mathrm{E}=\mathrm{N}>\mathrm{I}>\mathrm{M}>\mathrm{H}>\mathrm{L}>\mathrm{P}>\mathrm{Q}>\mathrm{K}>\mathrm{F}>\mathrm{G}>\mathrm{J}$ \\
\hline
\end{tabular}

\section{5 地域に与える交通施設整備の総合的影筹評価}

ここでは、3.(4)で論じたChoquet積分による総合評価法 で、トンネル建設とその効果の評価を行なってみる。わ れわれの主観に依存する総合評価は、加法性のみで評価 できない面があることをすでに論じてきた。ここでの評 価関数は、加法性の概念の代わりに、単調性すなわち包 含性（入れ子）に基ついて作成される。実際の調査結果 の例を紹介すると、全体での評価がトンネルの通行がで きたことにより、非常に良くなったと評価を与えてい る。例えば、通常の確率でその点数を 5 点満点とする と、約4.7点が与えられる。個々の評価項目では、最もよ い之評価された項目でも、約4.4点であり、総合評価值 は、平均点ではないことがわかる。すなわち、それぞれ の評価に相乗効果が働いており、それらの相乗効果を計 測する方法がここでは必要になる。

しかしながらその相乗性を厳密に把握するには、ここ で選択された17項目の相互の組み合わせでは217=131,072 のケースの評価が必要となる。現実的にはそのような検 討は難しいのでここでは、各評価項目の組み合わせ効果 の大きいのものを調査によって抽出し、その結果を総合 
評価値として導入することとした。

算定に当たって用いた条件は、以下に示す。

1)交通施設整備を評価する項目は、生活改善度17項目と する。また、相乗効果が考えられる組み合わせについて は、5つまで選択させ、記入する方法を採る。

2)各項目の重視度は、得られた交通条件の変化によって の期待度から、ファジィウェイトとして計算し、それら を小さい順に項目を並べかえる。組み合わせは、ウェイ トの高いもの 5 つを組み入れた。

3)評価基準を決定する関数は、それぞれの項目のグルー プ最近接ファジィ関数とする。

算出されたウェイトは、次のようになる。

$[\mathrm{H}, \mathrm{M}, \mathrm{I}, \mathrm{J},\{\mathrm{I}, \mathrm{H}, \mathrm{M}\}, \mathrm{L}, \mathrm{Q}, \mathrm{K}, \mathrm{C}, \mathrm{G}, \mathrm{D},\{\mathrm{C}, \mathrm{D}\}, \mathrm{A}, \mathrm{P}, \mathrm{F}, \mathrm{O}, \mathrm{N}, \mathrm{B}, \mathrm{E},\{\mathrm{N}, \mathrm{O}\}$ $,\{\mathrm{A}, \mathrm{B}\},\{\mathrm{B}, \mathrm{E}\}] \rightarrow[0.039,0.078,0.122,0.135,0.166,0.214,0.26$ $2,0.314,0.373,0.434,0.482,0.499,0.565,0.633,0.704,0.77$ $8,0.852,0.926,0.938,0.957,0.980,1.000]$

表 5 評価項目の評価得点（メンバーシップ值）

\begin{tabular}{|c|c|c|c|c|c|}
\hline 項目記号 & 地域全体 & 年齢 1 & 年齿 2 & 年齢 3 & 年路 4 \\
\hline $\mathrm{H}$ & 0.56 & 0.50 & 0.54 & 0.59 & 0.58 \\
$\mathrm{M}$ & 0.55 & 0.50 & 0.48 & 0.55 & 0.59 \\
$\mathrm{I}$ & 0.62 & 0.62 & 0.62 & 0.62 & 0.62 \\
$\mathrm{I}, \mathrm{H}, \mathrm{M}$ & 0.65 & 0.66 & 0.65 & 0.64 & 0.64 \\
$\mathrm{~J}$ & 0.45 & 0.44 & 0.44 & 0.48 & 0.41 \\
$\mathrm{~L}$ & 0.48 & 0.45 & 0.48 & 0.49 & 0.53 \\
$\mathrm{Q}$ & 0.47 & 0.43 & 0.42 & 0.50 & 0.51 \\
$\mathrm{~K}$ & 0.45 & 0.37 & 0.44 & 0.49 & 0.50 \\
$\mathrm{C}$ & 0.69 & 0.62 & 0.70 & 0.68 & 0.65 \\
$\mathrm{G}$ & 0.43 & 0.60 & 0.39 & 0.48 & 0.45 \\
$\mathrm{D}$ & 0.68 & 0.63 & 0.71 & 0.70 & 0.68 \\
$\mathrm{C,D}$ & 0.69 & 0.68 & 0.74 & 0.70 & 0.69 \\
$\mathrm{~A}$ & 0.67 & 0.67 & 0.69 & 0.67 & 0.67 \\
$\mathrm{P}$ & 0.51 & 0.44 & 0.51 & 0.54 & 0.52 \\
$\mathrm{~F}$ & 0.55 & 0.52 & 0.58 & 0.60 & 0.49 \\
$\mathrm{O}$ & 0.66 & 0.58 & 0.64 & 0.68 & 0.73 \\
$\mathrm{~N}$ & 0.59 & 0.50 & 0.59 & 0.62 & 0.63 \\
$\mathrm{~B}$ & 0.69 & 0.60 & 0.70 & 0.73 & 0.70 \\
$\mathrm{~N}, \mathrm{O}$ & 0.70 & 0.65 & 0.69 & 0.69 & 0.75 \\
$\mathrm{~A}, \mathrm{~B}$ & 0.72 & 0.70 & 0.73 & 0.71 & 0.72 \\
$\mathrm{E}$ & 0.67 & 0.69 & 0.69 & 0.68 & 0.63 \\
$\mathrm{~B}, \mathrm{E}$ & 0.70 & 0.72 & 0.73 & 0.72 & 0.71 \\
\hline
\end{tabular}

注）年齢 $1 ; 26-40$ 歳、年桻 $2 ; 41-50$ 歳、

年赫 $3 ; 50-65$ 歳、年路 $4 ; 65$ 歳以上

また地域全体および年齢グループごとに計算した評価 項目の評価值のメンバーシップ值を、表 5 に示す。

これらを用いて積分を行なった結果を表示すると、表 6 のようになる。

表 7 は、各グループで調査結果から得られた、直接の 総合評価值である。これらの結果を考察すると次のよう なことが明らかになる。
表 6 C hoquet 積分による総合評価結果

\begin{tabular}{|c|c|c|l|}
\hline グループ種類 & 可能性測度 & 必然性測度 & 中間測度 \\
\hline 地域全体 & $0.72(0.69)$ & $0.65(0.55)$ & $0.66(0.60)$ \\
年齢 1 & $0.72(0.69)$ & $0.55(0.48)$ & $0.68(0.62)$ \\
年齢 2 & $0.72(0.70)$ & $0.62(0.52)$ & $0.68(0.62)$ \\
年齢 3 & $0.76(0.73)$ & $0.65(0.55)$ & $0.70(0.63)$ \\
年齢 4 & $0.77(0.72)$ & $0.65(0.55)$ & $0.68(0.60)$ \\
\hline
\end{tabular}

注）グループ種類は表 6の注と同じである。また（）内は、組 み合わせを考慮しない場合の值である。

1)可能性測度を用いた場合、各評価項目の、最も大きな 評価値に近接した值となる。また必然性測度を用いた場 合、各評価項目の基準の平均値に近似している。 2)可能性・必然性測度の差は、地域全体の一部を構成す る各年齢グループの方が地域全体の場合より大きい。こ れは、グループとしての意見の安定性に依存しているも のと考えられ、可能性・必然性の様相を考えても妥当な 結果といえる。

3) 実際の調查による総合評価値（中央値）之様相性モ テリングでえられたメンバーシップ值を比較すると、調 查による評価値の方が全体的に大きめである。これは、 評価值相互の相乗性の影響と考えれるが、モデリングで は、若干の組み合わせによる評価が残っているため、や や過小に計測されていると考えられる。これは、いくつ かの組み合わせを導入した場合の評価値の上昇分を見て も明らかである。いずれにしても今回の交通施設の 1 つ としてのトンネル整備での総合評価は、相乗効果を含ん でいることが明らかになった。

表 7 調查で得られた総合評価值

\begin{tabular}{|l|c|c|c|}
\hline \multirow{2}{*}{ グループ種類 } & \multicolumn{3}{|c|}{ ファジィ評価値 } \\
\cline { 2 - 4 } & 下限値 & 中央値 & 上限值 \\
\hline 地域全体 & 0.62 & 0.74 & 0.85 \\
\hline 年齢 1 & 0.57 & 0.72 & 0.87 \\
\hline 年齢 2 & 0.56 & 0.70 & 0.84 \\
\hline 年齢 3 & 0.67 & 0.76 & 0.84 \\
\hline 年秢 4 & 0.67 & 0.76 & 0.84 \\
\hline
\end{tabular}

注）グループ種類は上表と同じである

\section{6.まとめと考察}

以上、交通施設整備の効果を住民の生活環境との関連 性で検討したが、次のような点で、従来の方法が改善さ れたと考える。i)従来この種の総合評価は、個々の属性 
の線形結合によるモデルが中心であったが、単調性の結 合により、属性の独立性の検証なしでモテル構築ができ た。ii)意思決定者（住民）がもともと持つ意見の幅を考 虑した様相性の概念を導入することで、思考プロセスに 忠実な再現性が可能となった。すなわち、人間の主観的 な判断は人間の持つ可能性と必然性の間での譲容幅の中 で検討すればよい。iii)様相性ファジィモデリングは、わ れわれが持つあいまい性、特に総合評価に関わるプロセ スの弾力性を直接モテル化することで、従来のモテルの 独立性の問題や、パラメータの意味付けなどが必要なく なったといえる。

今回の検討は、その第 1 歩に過ぎないが、今後、より 柔らかいシステムの構築、項目の組み合わせの影響相

乗、相殺効果等でのデータ加工の方法などいろいろ工夫 していきたいと考えている。

最後に、研究発表会で有益なコメントをいただいた広 島大学奥村誠先生に深甚なる謝意を表する次第である。

\section{7 学文献}

1)建設省編 : 平成 5 年度建設白書.

2)D.Dubois and H.Prade:Unfair doings and necessity measures:towards a possibilistic interpretation of histograms,Fuzzy Sets and System 10,pp15-60,1983.

3)室伏俊明、菅野道夫 : ファジィ測度入門III、日本ファジィ学 会誌、Vol.3 No.2,pp250-262,1991.

4)加賀屋誠一、菊池慎也 ; 可能性理論に基つくくァジィ意思決 定の地域整備効果評価への適用、土木学会北海道支部論文報告 集、pp789-794,1992.

5)加賀屋誠一：ファジィシステムによる道路粉塵影響の地域晾断 と改善策評価法、土木計画学研究・論文集、土木学会、 No.6,pp81-88.

6)椹木義一他 : 集団意思決定のための支嗳システム、オペレー ションリサーチ、No.11,pp39-46,1991.

7)室伏俊明、菅野道夫 ; ファジィ測度入門V,日本ファジィ学会 誌、Vol.3 No.4,pp49-58,1991.

ファジィモデリングによる地方交通施設整備の生活環境改善への影響評価

加賀屋誠一（北海道大学）・菊池慎也（テラウェア大学）

地方交通施設整備は、地域住民に対する多様な生活レベルに影響を与える。特に、過疎地域での道路整備 は、生活環境水準を高める偟きが大きい反面、交通の安全性や環境保全へのデメリットも考虑しなければな らない。

ここでは、交通施設整備による生活環境改善度。生活環境満足度を計測するためにそれらの奇与要因を抽 出し、地域住民の主観的評価によってファジィモテリングの構筑方法を考えた。主観的評価は、住民それぞ れが持つあいまい性や、主観性を表現するために、ファジィ測度で計測される。また、ファジィ測度による 評価は可能性から必然性までのゆらぎを考慮しながら検討する方法を考えた。それらの検討方法と手順は、 実際にトンネル建設による地域間の交通アクセスの改善を対象として実証的にその妥当性が確かめられた。

An Evaluation of a Local Traffic-Facility Construction on the Improvement of Living Environment Using Fuzzy Modeling

Seiichi Kagaya and Shinya Kikuchi

The new local transportation facilities provide a lot of influences on the multi-level of regional inhabitants' lives. The road improvement in depopulated areas, in particular, contributes to the promotion of level of living services. On the other hand, the demerits on the traffic safety and the environmental preservation should be evaluated. In this study the first aim is to construct the method in terms of fuzzy modeling which evaluates the subjective notion on the various factors of living environment. Such factors provide the degree of improvement and degree of satisfaction on the living environment in terms of the transportation facility improvement such as the improvement of access from depopulated areas to a local kernel city. The subjective values are indicated by the fuzzy measures in order to assess the vagueness which the inhabitants possess. The evaluation examined by several measures with the range from the possibility measure to the necessity measure. The accuracy of the proposed method and procedure were verified by the case of an actual construction of the tunnel for the improvement of the accessibility among the local towns. 